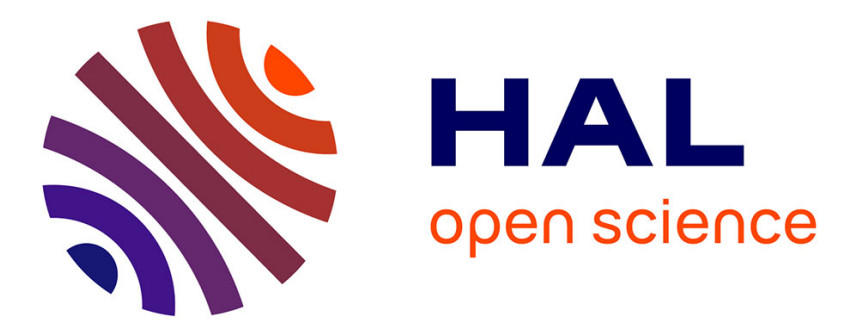

\title{
The Sustainability Challenges of Indigenous territories in Brazil's Amazonia
}

\author{
François-Michel Le Tourneau
}

\section{To cite this version:}

François-Michel Le Tourneau. The Sustainability Challenges of Indigenous territories in Brazil's Amazonia. Current Opinion in Environmental Sustainability, 2015, 14, pp.213-220. 10.1016/j.cosust.2015.07.017 . halshs-01241071

\section{HAL Id: halshs-01241071 https://shs.hal.science/halshs-01241071}

Submitted on 11 Dec 2015

HAL is a multi-disciplinary open access archive for the deposit and dissemination of scientific research documents, whether they are published or not. The documents may come from teaching and research institutions in France or abroad, or from public or private research centers.
L'archive ouverte pluridisciplinaire HAL, est destinée au dépôt et à la diffusion de documents scientifiques de niveau recherche, publiés ou non, émanant des établissements d'enseignement et de recherche français ou étrangers, des laboratoires publics ou privés. 
The Sustainability Challenges of Indigenous territories in Brazil's Amazonia

François-Michel Le Tourneau

Center for Research and Documentation on the Americas - CREDA, Paris 3 Sorbonne Nouvelle University and CNRS/National Center for Scientific Research

28 rue Saint Guillaume 75007 Paris - France

fmlt@fmlt.net

\section{Short abstract}

Indigenous territories now represent over $20 \%$ of the Brazilian Amazon. Well conserved for the most part, they play a key role in conservation and climate change mitigation, but are also undergoing drastic economic and social changes. Based on recent data, we depict current challenges and analyze what are the possible options for their sustainable development.

Long abstract

The overall context of Indigenous peoples in the Brazilian Amazon has changed dramatically since the 1980s. After the adoption of the 1988 constitution, large tracts of Indigenous lands have been recognized, which now cover more than $21 \%$ of the Brazilian Amazon. Well conserved for the most part, they play a key role in deterring deforestation and in climate change mitigation, while also undergoing drastic economic and social changes. There are many factors challenging the sustainability of Indigenous territories today, including the deficient enforcement of Indigenous rights. The injunction that Indigenous peoples should protect the environment is complicating the definition of which economic activities they are entitled to develop inside their territories. The focus of this paper is to review the current situation of Indigenous territories in the Brazilian Amazon, providing historical context and pointing out current challenges and the debates surrounding their sustainability. 


\title{
The Sustainability Challenges of Indigenous territories in Brazil's Amazonia
}

\author{
François-Michel Le Tourneau \\ Center for Research and Documentation on the Americas - CREDA, \\ Paris 3 Sorbonne Nouvelle University and CNRS/National Center for Scientific Research \\ 28 rue Saint Guillaume 75007 Paris - France \\ fmlt@fmlt.net
}

The Amazon holds a very important share of the world's biodiversity (more than $20 \%$ of all the world's fish, bird species or freshwater resources for instance), is a repository of cultural diversity with more than 375 Indigenous groups still retaining their language and culture, stocks enormous quantity of $\mathrm{CO} 2$ and has a continental and global influence on climate and hydrological cycles $(1,2,3,4)$. Today, due to new legislations and important changes in the attitude towards Indigenous peoples, officially recognized Indigenous territories cover over $21 \%$ of the Brazilian Amazon, including some of the most preserved areas. They thus constitute a very important element in the definition of the sustainability of the whole region with continental and global implications.

This is especially true in Brazil, which holds about two third of the Amazonian rainforest. The process of recognizing Indigenous land rights has been intense since the 1990s, following the 1988 Constitution which granted an exclusive and collective usufruct of all the soil and vegetation resources to Indigenous peoples, while the Federal Union is proprietary of the land itself. Although contested by some, Indigenous territories now account for more than 1.11 million $\mathrm{km}^{2}$ in the Brazilian Amazon. As they are very effective in inhibiting deforestation (5), they are considered as key areas for carbon sequestration and climate change mitigation $(6,7)$.

As a consequence of these elements, Indigenous peoples in the Brazilian Amazon are today facing new challenges. For most Amazonian Indigenous groups, the political struggle over land rights is no longer the priority ${ }^{1}$, as it has been the case until the early 2000s. Their agenda now include more complex and multifaceted challenges about how to manage their lands in order to meet their contemporary needs while meeting the exigencies expressed by Brazilian society about their contribution to environmental preservation.

This article reviews literature discussing the sustainability of the Indigenous territories of the Brazilian Amazon. To that end, we first review the emergence of Indigenous rights in Brazil, highlighting the importance of understanding historical factors underlying the current situation. We will then show that the relative (in)security of Indigenous territories and the potential vulnerabilities which arise from it are important factors which frame the definition of sustainability for such areas. Last, we will analyze the parameters under which Indigenous people can manage the environmental integrity and the economic development of their lands, showing that there are many constraints put on them, as well as new opportunities linked with the valorization of environmental services. As a

\footnotetext{
${ }^{1}$ Even if there are still many land conflicts in the Amazon about Indigenous land rights, especially when isolated groups are concerned.
} 
conclusion, we will question how an Indigenous reformulation of sustainability may emerge from the current situation.

\section{The late and conflictual emergence of Indigenous rights in Brazil}

The history of Indigenous peoples in Brazil has been filled with genocide, forced displacement and exploitation since the first contacts with the Portuguese (8). Estimations of the total Indigenous population at that time vary around 5 million people in 1500 (9). Some estimate a decline around $90 \%$ after the first century of colonization. In 1950, anthropologist Darcy Ribeiro estimated the population around 100,000 (10). Today, it is estimated that over 400,000 Indians live in the Amazon (see below).

Today's geographic distribution of the Indigenous peoples in the Amazon has little to do with what it was before the colonial conquest. Well organized and complex civilizations, which occupied the main rivers of the region and of which we know very little today; some experienced collapse early as is the case of populations inhabiting the Marajó island area and along the main courses of the Amazon, Madeira or Xingu valleys (11). Other were displaced, fleeing before the newcomers and trying to find safety in the remotest parts of the region like the Northwestern borders or the upper Rio Negro river. But even when they stayed away from white settlements, Indigenous peoples were subject to raids by slave traders (even if Indian slavery was in thesis prohibited) and to attraction by missionaries (12). At the same time many Indigenous groups also followed endogenous strategies of engagement and had their own goals, which levels of interactions with the colonial conquest varied much from one case to another.

Thus, an important consequence of the colonial conquest in the Amazon, which frames the contemporary situation, was the redistribution of its regional ethnic configuration. Some ethnic groups attempted large scale migrations in order to escape the destructive contact with white peoples and thus now occupy areas very distinct from their original homeland, like the Kayapó, who migrated from the northeastern savannahs to the State of Pará's rainforests, or the Wajãpi, who went from the Xingu River to the northern part of the State of Amapá. Many other simply disappeared. They also experienced an intense process of ethnogenesis (13), with disrupted groups merging into new tribes with renewed identities.

If during the XIX ${ }^{\text {th }}$ century, Brazil celebrated a fantasied Indianness in order to highlight its difference from its former colonial power, the situation of Indigenous peoples remained critical throughout the century, with brutal destruction and spoliation prevailing (14). Indigenous occupation of land, at that time, was considered illegitimate and their territories were seized as soon as farmers or planters would need them. Only at the beginning of the $X X^{\text {th }}$ century, under the influence of Marechal Cândido Rondon, did Brazil settle a protective policy for the Indigenous peoples. Until the 1970s, the main goal was the "integration" of Indians, which meant the progressive erasure of their distinctive cultural or social features (15). This was also the view adopted in the National Integration Plan (NIP) launched by the military government in 1970, during which several important infrastructures were constructed (like the Transamazonian highway), exposing previously uncontacted Indigenous groups like the Arara in Pará, the Panará in Mato Grosso and so many others, and inaugurating a new era of invasion and encroachment of traditional Indigenous territories. 
In line with the new global attitude towards Indigenous issues emerging since the 1960ies, during the 1970s a pro-Indian movement started confronting the NIP adverse impacts on the Indigenous peoples of the Amazon. Its audience widened considerably during the 1980s, when it made a political alliance with the environmental movement $(16,17)$. As a result, Indigenous peoples were presented as the best protectors of the rainforest during the RIOO-92 conference, at a time when Brazil was under heavy criticism due to intense deforestation in the Amazon. As we will show, this image still plays a critical role in defining what type of development or activities Indigenous peoples may legitimately develop on their lands.

The alliance with environmentalism and the political articulation of the pro-Indian movement were very influential during the preparaton of the new Brazilian Constitution adopted in 1988. In this text the definition of Indigenous land rights has been widened in order to encompass not only the areas actually occupied, but also all the space "necessary for the groups' physical and cultural survival according to their uses, customs and traditions" (article 231) (18). The land rights themselves are defined as an exclusive and collective usufruct of all the soil and vegetation resources, while the Federal Union remains proprietary of the land itself (and retains property and exploitation rights of the subsoil). Worth noting, some authors consider that such a definition makes Indigenous territories a type of common property, which may favor their sustainable management (19).

After the Constitution, also because of international financial support by the G7 program to the protection of tropical forests in Brazil $(20,21)$, the recognition of Indigenous territories "skyrocketed" in the Amazon, reaching more than $1111000 \mathrm{~km}^{2}$, or 21,7\% of the region's area (22). Although this figure is already considerable, the process is not over yet. New claims are still emerging from groups which remained invisible during decades and sometimes centuries, but which are today reclaiming their Indigenous identities (23). On the other hand, some demarcations made in the previous decades are today contested by Indigenous peoples who demand their expansion. This is the case for instance of the Manoki-Irantxe Indigenous territory in Mato Grosso which is currently 45555 ha in extension but in demand for revision and expansion up to 250,000 ha by the Indigenous population and the federal Indigenous agency (FUNAI).

\section{Theory vs practice of Indigenous rights: the relative (in)security of Indigenous territories}

Because it still holds very significant portions of unclaimed public lands, which are easier for the state to recognize as Indigenous, the process of Indigenous territories recognition has been more active in the Amazon. Today, Indigenous areas in this region accounts for $98.5 \%$ of all Indigenous areas in Brazil although holding only less than $50 \%$ of the total Indigenous population in Brazil according to the 2010 national census. Some Indigenous territories in this region are very extensive, like the Yanomami ( $96500 \mathrm{~km}^{2}$ ) or the Kayapo \& Xingu Indigenous Park complex (>140 $000 \mathrm{~km}^{2}$ ) Indigenous territories, which compare to medium-size European countries in area (Figure1). The mean size of Indigenous territories in the Amazon is about $2,983 \mathrm{~km}^{2}$ which is a rather important figure.

This success in Indigenous territorial demarcation is all the more remarkable because Indigenous peoples only form a small proportion of the regional population: there are about 433,000 Indigenous persons in the Amazon, or $2 \%$ of the overall Amazonian population ${ }^{2}$. Not all of them live in

\footnotetext{
${ }^{2}$ At a national level there are nearly 900,000 Indigenous persons in Brazil, or about $0.4 \%$ of the total population.
} 
Indigenous territories. About 110,000 Indigenous persons in the Amazon ( 25\%) live in towns or cities. Contrary to the acculturation theory, this does not necessary imply the loss of all connections to their former cultural universes. Some research pinpoint on the contrary the existence of circulatory migration strategies where spending months and sometimes years in the city is part of the Indigenous life cycle $(24,25,26)$. Furthermore, many Indigenous communities today maintain houses in the city in order for their members to access specific resources or services (markets, advanced medicine or education, etc.).

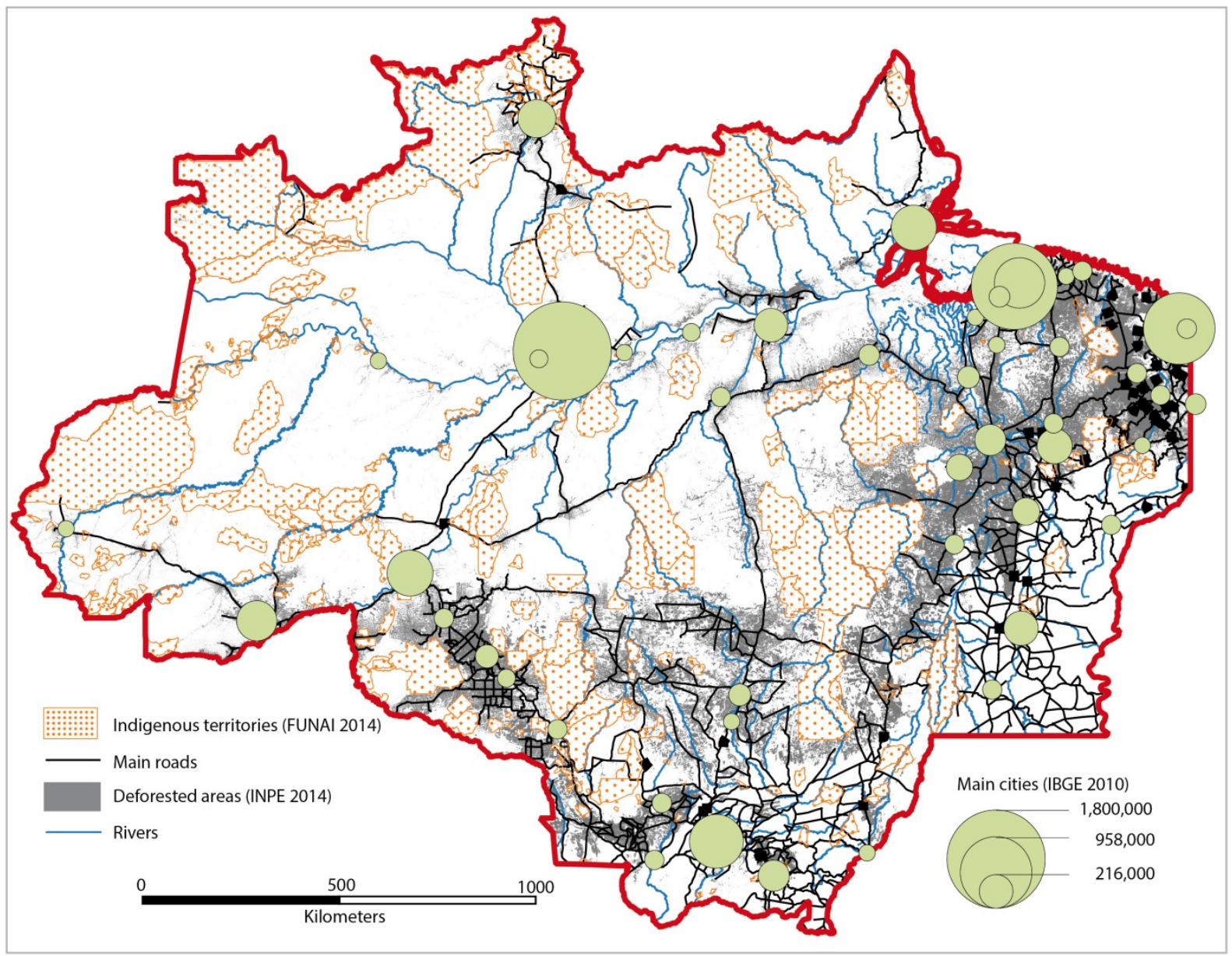

Although it is based on constitutional rights, the security of Indigenous territories under the current political system in Brazil is not absolute. The Brazilian Congress has always opposed large Indigenous territories and its longstanding request is to be granted a veto right on the recognition process ${ }^{3}$. Many politicians also advocate the downsizing of large Indigenous territories, without success until now due to constitutional provisions ${ }^{4}$. But several legal devices, like the informed consultation right ${ }^{5}$, were already overlooked in the case of the iconic Belo Monte dam (27), showing the fragility of Indigenous territories legal protection and environmental conservation when state interests are at stake.

Also, the current government has developed a restrictive view on Indigenous peoples land rights, because the creation of new Indigenous territories is seen as blocking the path for new infrastructure

\footnotetext{
${ }^{3}$ Proposal of constitutional amendment (PEC) $n^{\circ} 215$.

${ }^{4}$ This however, already happened with protected areas which also enjoy constitutional protection.

${ }^{5}$ Granted by the ILO 169 convention ratified by Brazil.
} 
projects, like dams or roads. It proposed that other administrations (like the Ministry of agriculture, which is in general not in favor of Indigenous land rights) should be consulted in the process of analyzing the future Indigenous territories whereas FUNAI has been exclusively in charge. However this decree has yet to be published. On the other hand, the federal government has also acted at times in order to enforce granted rights, such as the case in 2012 when hundreds of encroached families were removed by force from the Xavante territory in central Brazil named Marawaitsede, after three decades of juridical conflict.

From the political point of view, an important change since the late $X X^{\text {th }}$ century is that the political pressure in favor of Indigenous peoples is today exerted by the Amerindian movement itself and less directly by support non-Indigenous organizations. Amerindian associations have appeared throughout the Amazon, and Indigenous leaders have also emerged (28). They tend to be well educated, fluent in Portuguese, well aware of how the Brazilian political and juridical systems work (29) and understand well the international pressure on Brazil's environmental record. They have formed also dense regional networks, like the COIAB, the coordination of the Indigenous peoples of the whole Amazon region (30). They also maintain ties with international NGOs or with different corporations $(31,32)$ and are expert in counterbalancing their small demographics by important well articulated exposure to the media inside or outside Brazil. For instance they organize high profile symbolical acts in state capitals or in the Brazilian capital Brasília. Today, a national representative commission ${ }^{6}$ is to be consulted (at least in theory) when new public policies are launched at state or national level with direct implications for Indigenous rights. Even if this is still controversial, Indigenous peoples are now generally considered as a stakeholder, especially in the Amazon where they control an important part of the region.

However, the debate over Indigenous territories still rages in Brazil 20 years after the adoption of the 1988 Constitution, in almost the same terms today than as in the past, with the pro-farmer lobby of the Congress denouncing that there is "too much land for too few Indians". As a result neither the new statute for Indigenous peoples and communities ${ }^{7}$ neither the new mining code (which should provide guidelines on how subsoil resources may be exploited in the Indigenous territories) have been adopted by the Brazilian Congress despite more than 20 years of talks and negotiations.

Enforcement of the protection of Indigenous territories ${ }^{8}$ is a critical issue conditioning the path towards sustainability. Because they hold valuable resources, some of which are depleted in other regions, Indigenous territories are facing strong external pressures. They are regularly invaded by wildcat gold miners, ranchers, loggers, etc. Well known cases are : the Awá or Araribóia Indigenous territories in Maranhão (encroachment by loggers); Arara and Cachoeira do Iriri Indigenous territories near the Transamazonian Highway, the Baú Indigenous territory in Pará (encroachment by farmers); the Cinta Larga territory in Mato Grosso (encroachment by illegal diamond miners), to name just a few. Operations are regularly launched by the federal authorities but their pace is insufficient to curb the invasions. In the Yanomami territory, for instance, despite numerous operations and more than 20 years of struggle, gold panners still continue to operate clandestine airstrips (33). The consequences of such invasions are serious, not only from the environmental point

\footnotetext{
${ }^{6}$ National commission for Indigenous Policy - CNPI, which should be transformed into a permanent body if the law project 3571/2008 is approved.

${ }^{7}$ Which should replace the 1973 text, totally contradicted by the current Constitution.

${ }^{8}$ Where access is prohibited in principle to all non-Indigenous people.
} 
of view, but also because the invader's presence disseminates diseases which are lethal to Indigenous populations (flu, malaria, tuberculosis, etc.).

Last, even if the Constitution and laws in Brazil make large provision for Indigenous peoples as far as bilingual education, health or protection are concerned, enforcement of these issues is also insufficient. As a result of these flaws, the social situation is in general very difficult inside the Indigenous territories of the Amazon. Health and social indices are among the worst in Brazil: infant mortality rate is much higher than the national, tuberculosis or malaria prevalence are extremely high $(34,35)$, nutrition problems are commons and alcoholism or suicide are widespread. Indigenous peoples must always keep a political pressure on the federal government (for instance by invading regional offices of the health administration) in order to be granted the necessary. Also, the federal administration in charge of Indigenous peoples, the FUNAI, has consistently proved weak and inefficient. As one can imagine, those factors create a situation of continuous emergency in which long term planning of the territories' sustainability is not always a priority.

\section{Managing environmental integrity and economic development in the Indigenous territories}

In a context of accelerated cultural and social changes driven by a wider contact with the Brazilian society and accelerated demographic growth $(36,37)$, the Indigenous peoples of the Amazon face today some kind of double bind which comes directly from the condition under which they have conquered their recognition. On the one hand, they must guarantee the environmental integrity of their lands since the protection of the rainforest was a constant argument in their favor. What was an indirect obligation is becoming a requirement since the federal government now considers Indigenous territories as environmental protection areas ${ }^{9}$ and has defined a national policy for their environmental management ${ }^{10}$. On the other hand, they need to find new economic activities in order to access western goods which are now part of their way of life (from basic tools to household goods such as freezers, TV sets and cell phones). Thus, the Indigenous territories of the Amazon today face the challenge of finding their sustainability (38) in a context of change. In this context their "traditional" production systems must be reformulated in order to yield monetary incomes which in many cases have been very peripheral until the recent years.

Hunting is a paradigmatic example of how those changes are taking place and of what the consequences are. It is still a pillar of the subsistence and way of life for many Indigenous groups. In many cases, the sustainability of hunting activities was guaranteed by norms, beliefs, and taboo systems, as well as technological limitations and frequent mobility that maintained low environmental pressure (38). Today, the wider availability of guns, eventual sales of game on the market and the diminishing influence of old beliefs and worldviews lead towards an increased impact of Indigenous hunting on the environment (39), with the risk of local extinction of some of the most hunted species. Given this scenario, many groups face the challenge of adapting and aligning existing cultural norms and rules with fast changing conservation policies governing (40). These changes will represent new ways for Indigenous groups to think about their territories. Likewise, Indigenous groups continue to seek new means of securing income in ways compatible with social conditions and environmental regulations.

\footnotetext{
${ }^{9}$ Decree $n^{\circ} 6040$ of $02 / 07 / 2007$.

${ }^{10}$ National Policy of Environmental Management of Indigenous Lands - PNGATI, 06/05/2012 decreto $n=7.747$.
} 
Such alternatives are not straightforward. First, the question of how Indigenous peoples may commercialize natural resources from their territories is a difficult one. Selling timber, fish or exploiting alluvial gold, for instance, which are activities permitted according to the Constitution, implies a risky loss of symbolical capital, as the Wajãpi of Amapá or the Tukano of the Alto Rio Negro experienced during the 1990s when they tried to exploit gold in their rivers. Also, such activities will probably be banned with the new environmental management policy for Indigenous territories. Based on ethnomapping and zoning, each territory will have to elaborate a management plan aiming at environmental conservation $(41,42)$.

Another way to gain income from natural resources is to increase the production of handcraft, agricultural or non-timber forest products, like the Baniwa whose baskets are commercialized in furniture stores in São Paulo. But not every village is connected to a potential market and commercialization in fair trade circuits is not easy nor always profitable $(43,44)$. Productive activities were encouraged by special financing schemes in the 2000s, but with mixed results, either because of the difficult intercultural relationship between Indigenous peoples and non-Indigenous technicians involved in these projects (45) or, more generally, because they implied a capitalist orientation that more often than not conflicts with Indigenous social norms and cosmology (some authors have noted however that these relationships can be different among those influenced by Evangelic missionaries, see 46), as the frustrating attempts of the Body Shop multinational with the Kayapó clearly showed. Furthermore, agricultural activities may result in land cover change which raises the same environmental and symbolical issues as above. The Parcecis, for instance, grow soy bean and earn very good return for it, which allowed for cultural revival in many villages, but this activity has been condemned by outsiders as "non-traditional" (47). Furthermore, as far as land cover conversion or agricultural practices are concerned, the options for Indigenous peoples will be more limited in the future because of the limits imposed by environmental management plans as mentioned above.

The cultural and environmental conditions of Indigenous territories may create new opportunities for ecotourism activities (48), but as of now, this activity is not allowed by the FUNAl, which is still working on a proposal to regulate this activity. Also, the potential impacts of ecotourism activities are uncertain (49), and oversimplifying the Indigenous context and inner rivalries may lead to impasses as was the case observed among the Kayapó (50).

Various forms of financial compensation are developing in the region. Some Indigenous groups already charge tolls when roads cross their territory (case of the Parecis in Mato Grosso or the Tenharim in Amazonas, for instance). In other cases, "environmental compensations" are granted when a territory is impacted by roads, mines, transmission lines or dams (as the case of the Waimiri Atroari in Amazonas and the Xikrin in Pará). But they are in general reluctant since those projects also have environmental impacts which may affect dramatically their sustainability. Indigenous peoples of the Xingu thus have continuously opposed the Belo Monte project, even when granted millions in "environmental compensations" for fear that the dam may affect the fish which are their primary source of protein.

Much hope is placed today in the valorization of environmental services provided by Indigenous territories in the Amazon. This would be a logical counterpart to their designation as protected areas and their role in efficiently deterring deforestation in several regions $(51,6)$. But the process has been slow due to the absence of a well-defined legal framework for Indigenous territories, although 
this is slowly moving forward (52). Also, how benefits are to be shared among villages, communities and individuals is a difficult and unresolved issue $(53,54)$. If the Suruí project $(55)$ appears as a model, as for now few Indigenous peoples have found substantial financing mechanisms, although many have been approached by the so-called "carbon cow-boys" (as the case of the Munduruku who were approached by an Irish company interested in buying carbon compensation rights for 30 years, a deal later denounced by FUNAI).

Today, social benefits and a number of local jobs (such as teachers, health assistants, etc.) constitute the major income sources inside many Indigenous territories in the Amazon ${ }^{11}$. This is a mixed situation. If, on the one hand, it allows the access to industrialized goods without important changes to Indigenous production systems, on the other hand it creates a dependency towards public policies. Last, as cash is now more easily available through governmental programs, there is a tendency in some villages to rely increasingly on purchased food than on local agriculture. These trends may jeopardize Indigenous autonomy and further accelerate a process of nutritional transition as observed in a recent survey of Indigenous populations in Brazil (56).

\section{Conclusion: towards Indigenous reformulations of sustainability?}

When it comes to territorial rights, the Indigenous peoples of the Amazon are a step ahead of other Indigenous groups of Brazil. Today they are challenged to find sustainable alternatives to manage their territories. Given the global stakes of the environmental preservation of the Amazon, this challenge has local (maintaining the Indigenous territories according to each group's needs and philosophy) and global (preserving the rainforest in order to mitigate climate change and biodiversity erosion) dimensions.

Defining sustainability in this context is a complex task, especially as most Indigenous groups are experiencing social and cultural change moving them ever farther from the image of huntergatherers lost in the rainforest which most people, including Brazilians, have about them. At the same time, the inner perceptions of Indigenous communities about environment are still shaped by their distinct cultural history and cosmology, which are now shaping the way many groups negotiate the relations with outsiders and their expectations (57).

Until now, most "sustainable" initiatives in Indigenous territories were conducted according to Western definitions of this concept and have yielded mixed results. Moreover, other types of economic activities are also judged as in function of the way sustainability is defined by outsiders. Improving this situation implies new forms of intercultural dialogue and resecting their own definition of sustainability. It is important to remember that that they have been managing tropical rainforests and biodiversity for centuries (58) and are in a position to advice and collaborate with Western science in new ways to do so.

\section{References}

[1] Saatchi SS, Houghton RA, Dos Santos Alvala RC, Soares JV and Yu Y: Distribution of aboveground livebiomass in the Amazon basin. Global Change Biology 2007 13:816-837.

\footnotetext{
${ }^{11}$ In December 2014, 58111 Indigenous families were receiving the Bolsa Família benefit in the Amazon region according to the Ministery of Social Development's statistics (see http://aplicacoes.mds.gov.br/sagi/Rlv3/geral/index.php).
} 
[2] Gibson L, Lee TM, Koh LP et al.: Primary forests are irreplaceable for sustaining tropical biodiversity. Nature 2011 478:378-381. doi:10.1038/nature10425

[3] Ter Steeg H: et al. Hyperdominance in the Amazonian tree flora. Science 2013 342:6156, doi: 10.1126/science.1243092.

[4]Baccini A, Goetz SJ, Walker WS, et al.: Estimated carbon dioxide emissions from tropical deforestation improved by carbon-density maps. Nature Climate Change 2012 2:182-185 doi:10.1038/nclimate1354

[5] Nolte C, Agrawal A, Silvius KM, Soares-Filho BS: Governance regime and location influence avoided deforestation success of protected areas in the Brazilian Amazon. Proceedings of the National Academy of Sciences 2013 110(13):4956-4961, doi:10.1073/pnas.1214786110

[6] Ricketts TH, Soares-Filho B, da Fonseca GAB, Nepstad D, Pfaff A, et al.: Indigenous Lands, Protected Areas, and Slowing Climate Change. PLoS Biol 2010 8(3):e1000331.

doi:10.1371/journal.pbio.1000331

[7] -Walker W, Baccini A, Schwartzman S, Ríos S, et al.: Forest carbon in Amazonia: the unrecognized contribution of Indigenous territories and protected natural areas. Carbon Management 2014 DOI: 10.1080/17583004.2014.990680 [Shows that there are almost 2,300 Indigenous territories in the Amazon and quantifies carbon stocks within them. Assesses pressures and risks and shows that specific policies are required, especially in order to recognize all Indigenous territories and to enforce existing land rights.]

[8]Gomes M: The Indians and Brazil. University of Florida Presses: 2000.

[9]Fausto C: Os índios antes do Brasil [Indians before Brazil] São Paulo: Jorge Zahar, 2000 [10] Ribeiro D: Os Índios e a civilização: a integração das populações indígenas no Brasil moderno [The Indians and the civilization: the integration of Indigenous population in modern Brazil], São Paulo:Companhia das letras, 1996[1970]

[11] -Goes Neves E: Was agriculture a key productive activity in pre-colonial Amazônia? The stable productive basis for social equality in the central Amazon. In HumanEnvironment interactions: current and future directions. Edited by Brondizio E and Moran E. Springer; 2013:371-387. [Shows that Amerindian agriculture in the Amazon before colonization was not exclusively slash and burn shifting cultivation, but that there were spots of intensive sedentary agriculture which indicate that appropriated technology existed which prevented soil degradation. Such an agriculture was the basis of large scale settlements which collapsed soon after the colonial conquest.]

[12] Hemming J: Red Gold: The Conquest of the Brazilian Indians. London: Pan Macmillan, 1978.

[13] Pacheco de Oliveira Filho J: Uma etnologia dos 'índios misturados'? Situação colonial, territorialização e fluxos culturais. [An ethnology of 'mixed Indians' ? Colonial situation, territorialization and cultural exchanges] Mana. Estudos de Antropología Social 1998 4(1):4777.

[14] Devine Guzman T: Native and National in Brazil: Indigeneity after Independence. Chapel Hill: UNC Press, 2013.

[15] Hemming J: Die If You Must: Brazilian Indians In The Twentieth Century (v. 3), Pan Books:2004

[16] Beth A, Conklin L, Graham R: The Shifting Middle Ground: Amazonian Indians and EcoPolitics. American Anthropologist 1995 97(4):695-710. doi: 10.1525/aa.1995.97.4.02a00120 [17] Schwartzman S, Zimmerman B.: Conservation Alliances with Indigenous peoples of the Amazon. Conservation Biology 2005, 19(3): 721-727. 
[18] Moog Rodrigues MG: Indigenous Rights in Democratic Brazil. Human Rights Quarterly 2002 24(2): 487-512

[19] Lauriola VM: Indigenous lands, commons, juridical pluralism and sustainability in Brazil: lessons from the Indigenous lands of Raposa Serra do Sol. Journal of Latin American Geography, 2013, 12(1):157-185.

[20] Moreira Lima LM 2005, Se a Funai não faz, nós fazemos: conflito e mudança no contexto de um projeto de cooperação [If FUNAI won't do, we will: conflicts and changes in the context of a cooperation project], Phd thesis

[21] FUNAI: Demarcando Terras Indígenas: Experiências e Desafios de um Projeto de Parceria (vol $1 \& 2$ ) [Demarcation of Indigenous territories : experiences and challenges of a partnership project]. Brasília: FUNAI, PPTAL, GTZ : 1999 and 2002.

[22] • Carneiro Filho A, Braga de Souza O: Atlas of pressures and threats to Indigenous lands in the Brazilian Amazon. 2009 São Paulo:ISA [Provides maps and charts about the situation of Indigenous territories in the Brazilian Amazon, showing localization of Indigenous regions but also the threats represented by dams, mining concessions, deforestation or the expansion of cattle ranching; updated edition 2013 in portuguese]

[23] Rodrigo Correa Peixoto, Karl Arenz, Kércia Figueiredo, O Movimento Indígena no Baixo Tapajós: etnogênese, território, Estado e conflito [The Indigenous movement in the lower Tapajós region: ethnogenese, territory, state and conflict]. Novos Cadernos NAEA, Vol. 15, No 2 (2012) [24] Baines SG : As chamadas "aldeias urbanas" ou índios na cidade [The so-called 'urban Indigenous villages' or the Indian in the city] . Revista Brasil Indígena 2001. Brasília: FUNAI 1(7):15-17.

[25] Eloy L: Diversidade alimentar e urbanização: o papel das migrações circulares indígenas no Noroeste Amazônico. Anthropology of food 2009, 6.

[26] Teixeira P, Mainbourg MT, Brasil M: Migração do povo indígena Sateré-Mawé em dois contextos urbanos distintos na Amazônia. Caderno Crh, 2009, 22(57):531-546.

[27] Fujishima S: The Legality of the Belo Monte Hydroelectric Construction From The Perspective of Indigenous Land Rights. Indigenous Policy Journal 2014 24(4):2158-4168. [28] Albert B: Territoriality, Ethnopolitics, and Development: The Indian Movement in the Brazilian Amazon. In The Land Within: Indigenous Territory and the Perception of the Environment. Edited by Surrallés A and García Hierro P. Denmark: International WorkGroup for Indigenous Affairs; 2005:200-233.

[29] • Belleau JP: Le mouvement indien au Brésil [the Indian political movement in Brazil]. Presses universitaires de Rennes: 2014. [This book recalls the history of the creation and early period of the Amerindian movement in Brazil. This movement started during the 1970s under the tutelage of a body of the Catholic church, the CIMI, and was later supported by several NGOs. The author shows how forms of action were adopted by Indigenous communities and leaders according to their own cultural background. It focuses on the history of several of the first Indigenous leaders.]

[30] Heck E, Loebens F and Carvalho PD: Amazônia indígena: conquistas e desafios [Indigenous Amazonia: conquests and challenges ahead]. Estudos avançados 2005 19(53):237255.

[31] Zanotti L: The Politics of Possession: The Proliferation of Partnerships in the Brazilian Amazon Polar-political And Legal Anthropology Review 2011 34(2):290-314. [32] de Robert P: Conflitos, alianças e recomposições territoriais em projetos de desenvolvimento sustentável : experiências da Terra Indígena Kayapó (Sul do Pará) [Conflicts, aliances and territorial recompositions in sustainable development project : the Kayapó 
case]. In : Desenvolvimento sustentável e sociedades na Amazônia. Edited by Araujo R and Léna P. Belém: Museu Paraense Emilio Goeldi, 2010:333-354.

[33] Le Tourneau F-M : Les Yanomami du Brésil, géographie d'un territoire amérindien [The Yanomami of Brazil, geography of an Indigenous territory], Paris:Belin. 2010.

[34] Coimbra CEA and Basta PC: The burden of tuberculosis in Indigenous peoples in Amazonia, Brazil. Trans R Soc Trop Med Hyg 2007, 101(7): 635-636.

[35] Mel T, Resendes AP, Souza-Santos R and Basta PC: Distribuição espacial e temporal da tuberculose em indígenas e não indígenas de Rondônia, Amazônia Ocidental [Spatial and temporal distribution of tuberculose in Indigenous and non-Indigenous populations of Rondônia, occidental Amazonia]. Cadernos de Saúde Pública. 2012, 28(2):267-280

[36] Pagliaro H: The demographic revolution among Brazilian Indigenous peoples: the case of the Kayabi in the Xingu Indian Reservation, Mato Grosso State, Brazil, 1970-2007.

Cadernos De Saude Publica 2010, 26(3):579-590.

[37] Ventura Santos R, Coimbra Jr CEA, Welch JR: A Half-Century Portrait: Health Transition

in the Xavante Indians from Central Brazil. In Human-Environment interactions: current and future directions. Edited by Brondizio E and Moran E. Springer; 2013:29-52

[38] Shankland A: Reimagining Development with Indigenous People: Reflections from the Sao Gabriel da Cachoeira Workshop. Ids Bulletin-institute Of Development Studies 2011 42(5):24-29.

[39] Prado HM, Forline LC, Kipnis R: Hunting practices among the Awá-Guajá: towards a long-term analysis of sustainability in an Amazonian Indigenous community. Boletim do Museu Paraense Emílio Goeldi. Ciências Humanas, 2012, 7(2):479-491.

[40] Shepard Jr GH, Levi T, Góes Neves E, Peres C, Yu D: Hunting in Ancient and Modern Amazonia: Rethinking Sustainability. American anthropologist, 2012, 114(4):652-667 [41] Little P: Gestão territorial em terras indígenas: Definição de Conceitos E Proposta de Diretrizes [Territory management of Indigenous lands : concepts, definitions and a proposal for a way forward]. Rio Branco: SEMA-AC/SEPI-AC ; Brasília: GTZ; 2006.

[42] Barreto Filho H (org): Mapeamentos participativos e gestão de territórios indígenas na amazônia [Participatory mapping and environmental management in Amazonia]. Brasília: Amazônia Indígena: 2012

[43] D'Almeida Martins R: Fair trade practices in the Northwest Brazilian Amazon. BAR, Braz. Adm. Rev. 2011 8(4): 412-432.

[44] Clay J: Os Kayapós e a Body Shop: a parceria de comercio com ajuda [The Kayapo and the Body Shop corporation: a partnership of trade and aid]. In Esverdeando a Amazônia :

comunidades e empresas em busca de práticas para negócios sustentáveis. Edited by Anderson A and Clay J. São Paulo : Peirópolis ; Brasília : IIEB; 2002:31-52.

[45] Little PE: Indigenous peoples and Sustainable Development Subprojects in Brazilian Amazonia: The Challenges of Interculturality. Law \& Policy 2005 27(3): 450-471.

[46] Wright RM, Kapfhammer W and Braune Wiik F: The Clash of Cosmographies: Indigenous Societies and Project Collaboration - Three Ethnographic Cases (Kaingang, Sateré-Mawé, Baniwa). Vibrant: Virtual Brazilian Anthropology 2012 9(1):382-450.

[47] Centro de Monitoramento de Agrocombustíveis: Impactos da soja sobre Terras Indígenas no estado do Mato Grosso [Impact of soybean on Indigenous territories in the state of Mato Grosso], Reporter Brasil:2010.

[48] Da Silva G: Atividades turísticas nas terras indígenas brasileiras: abordagem analítica e proposta de regulamentação [Tourism in Indigenous territories, an analytic approach and a 
proposal for regulamentation], MA Florianópolis / Universidade de león fundação universitária iberoamericanamestrado em gestão e auditorias ambientais: 2010

[49] Quaresma H, de Almeida Barbosa D: Turismo na terra de Macunaíma: sustentabilidade em parques nacionais da Amazônia [Turism in the land of Macunaíma : sustainability in National Parks of the Amazon]. PhD Thesis Universidade Federal do Pará, Núcleo de Altos Estudos Amazônicos, Programa de Pós-Graduação em Desenvolvimento Sustentável do Trópico Úmido, Belém, 2008.

[50] Chernela J and Zanotti L: Limits to Knowledge: Indigenous Peoples, NGOs, and the Moral Economy in the Eastern Amazon of Brazil, Conservation and Society, 2014 12(3):306-317.

[51] Nepstad D, Schwartzman S, Bamberger S, Santilli et al.: Inhibition of Amazon deforestation and fire by parks and Indigenous lands. Conserv Biol 2006 20(1):65-73. [52] Shankland A and Hasenclever L: Indigenous peoples and the Regulation of REDD plus in Brazil: Beyond the War of the Worlds? Ids Bulletin-institute Of Development Studies 2011 42(3):80-88.

[53] Anderson N: REDDy or not? The Effects on Indigenous peoples in Brazil of a Global Mechanism for Reducing Emissions from Deforestation and Degradation. Journal of Sustainable Development 2009 2(3):18-28.

[54] -Nery D, Christovam M, Mesquita I, Splendore J et al.: Indigenous peoples and the reducing emissions from deforestation and forest degradation (redd+) mechanism in the Brazilian Amazon: Subsidies to the Discussion of Benefits Sharing. Brasília, DF: Instituto de Pesquisa Ambiental da Amazônia, 2013. [Analyzes existing REDD projects in Indigenous territories of the Brazilian Amazon as well as the absence of a well defined legislative framework. Gives examples of negative and positive impacts and brings recommendations based on a dialogue with representative Indigenous associations]

[55] Vitel C, Nathalie MS, Cardoso Carrero G et al.: Land-Use Change Modeling in a Brazilian Indigenous Reserve: Construction of a Reference Scenario for the Suruí REDD Project. Human Ecology 2013 41(6):807-826.

[56] - Coimbra CEA, Ventura Santos R, Welch JR et al.: The First National Survey of Indigenous People's Health and Nutrition in Brazil: rationale, methodology, and overview of results. BMC Public Health 2013 13:52 [Analyzes the results of the first national survey of Indigenous people's health in Brazil. Based on a representative sample of 113 villages, it shows that health indicators are worse than the Brazilian average in most cases, and that the nutrition transition is occuring at an accelerated pace.]

[57] •Virtanen PK, Saarinen S, Kamppinen M: How to integrate socio-cultural dimensions into sustainable development: Amazonian case studies, International Journal Sustainable Society, 2012, 4(3):226-239. [This article deals with the relation between people and environment in Indigenous societies. In most of the Amazon, the environment is seen as a world of subject in dialogue with human societies, and people must negotiate with the "keepers" in order to hunt or fish. This interpretation of the environment remains strong even if technologies have changed. Moreover, contemporary issues, like the necessity to interact with urban areas or administrations in order to manage the territory, are now interpreted according to similar schemes.]

[58] Schwartzman S, Villas Boas A, Yukari Ono K, Gesteira Fonseca M et al.:, The natural and social history of the Indigenous lands and protected areas corridor of the Xingu River basin. Phil. Trans. R. Soc. B 2013 368:20120164 DOI: 10.1098/rstb.2012.0164 